\title{
A Primer on Exporting to Jamaica 1
}

\author{
Christina D. Storz, Timothy G. Taylor, and Gary F. Fairchild ${ }^{2}$
}

\section{Introduction}

Every year the U.S. Department of State publishes extensive Country Commercial Guides for a large number of countries. These guides provide a great deal of information useful to individuals interested in developing export markets either through direct exports or through direct foreign investment. This paper provides an abridged version of the Country Commercial Guide for Jamaica as well as supplemental information of direct relevance to agribusiness firms. It is hoped that the information contained in this report provides a useful starting point for individuals interested in exploring export or investment opportunities in Jamaica.

Note: County Commercial Guides are available for U.S. exporters from the National Trade Data Bank's CD-ROM or via the Internet. Please contact Stat-USA by telephone (1-800) STAT-USA for more information. Country Commercial Guides can be accessed via the World Wide Web at http://www.stat-usa.gov, http://www.state.gov, and http://www.mac.doc.gov. They can also be ordered as a hard copy or on diskette from the National Technical Information Service (NTIS) by telephone (1-800) 553-NTIS. American exporters seeking general export information/assistance and country-specific commercial information should contact the U.S. Department of Commerce, Trade Information Center by telephone (1-800) USA-TRADE; or by fax (202) 482-4473.

\section{Economic and Political Overview}

Jamaica is the largest English-speaking island in the Caribbean, with a small but diversified economy and many natural resources. Jamaica's nominal GDP (Gross Domestic Product) for 2002 was US\$7.29 billion. Although the island's population of 2.6 million and modest per capita income of roughly US\$2,786 limit investment for the domestic market, there is potential for export-oriented activities. Primary markets for U.S. exporters are in tourism, telecommunications, mining (bauxite/alumina and limestone), agribusiness, utilities, infrastructure (roads and port facilities), and other aspects of construction. There are also opportunities in niche markets such as eco-tourism, health tourism, nutraceuticals, film, and music.

The United States remains Jamaica's primary trading partner. In 2002, merchandise imports to Jamaica from the United States amounted to US\$1.6 billion, compared to US $\$ 1.5$ billion in 2001. Major U.S. imports from Jamaica in 2002 included bauxite/alumina (US\$700 million), chemicals

1. This is EDIS document FE516, a publication of the Department of Food and Resource Economics, Florida Cooperative Extension Service, Institute of Food and Agricultural Sciences, University of Florida, Gainesville, FL. Published February 2005. Please visit the EDIS website at http://edis.ifas.ufl.edu.

2. Christina D. Storz, Research Assistant; Timothy G. Taylor, Professor; and Gary F. Fairchild, Professor, Department of Food and Resource Economics, Florida Cooperative Extension Service, Institute of Food and Agricultural Sciences, University of Florida, Gainesville, FL.

The Institute of Food and Agricultural Sciences is an equal opportunity/affirmative action employer authorized to provide research, educational information and other services only to individuals and institutions that function without regard to race, color, sex, age, handicap, or national origin. For information on obtaining other extension publications, contact your county Cooperative Extension Service office. Florida Cooperative Extension Service/Institute of Food and Agricultural Sciences/University of Florida/Christine Taylor Waddill, Dean. 
(US\$57.2 million) and food (US\$50.0 million).

Tourism was Jamaica's largest foreign exchange earner until 2002 when remittances also contributed US $\$ 1.2$ billion to the economy.

Government regulations, including labeling and veterinary requirements, Customs bureaucracy, and high tariff barriers, are some of the factors impacting exports to Jamaica. Additionally, the fiscal and external accounts continue to be the most challenging areas of macroeconomic management. The government's huge appetite for domestic debt and increased foreign exchange market instability led to an upward trend in interest rates during 2002. However, the Jamaican government encourages foreign investment through a variety of incentives to facilitate growth. Investor incentives include low wage rates relative to the United States, close proximity to the U.S. market, and preferential market access to the United States.

Following four years of decline in real GDP (1996-1999), the economy recorded its third consecutive year of growth in 2002. Real GDP grew by an estimated $1 \%$, following the $1.7 \%$ increase in 2001 and $0.7 \%$ increase in 2000 . The growth in 2002 was largely due to expanded output in mining, construction transport, storage, communications, financial services, and construction. Jamaica also recorded its sixth successive year of single digit inflation, the longest single digit run since the 1960s. The most significant economic development to date for 2003 was the presentation of the 2003-2004 fiscal budget, which focuses on the generation of a balanced budget and a reduction of the debt to GDP ratio.

The agriculture sector generates approximately $7 \%$ of the GDP and employs over $20 \%$ of Jamaica's employed work force. Major traditional export crops include sugar, bananas, coffee and citrus. Other major non-traditional crops include yams, tropical fruits and vegetables, and horticulture. However, there are several challenges facing the agriculture sector, including the loss of preferential markets for bananas and sugar, high production costs, and susceptibility to the elements (e.g., flooding and drought).

\section{Marketing U.S. Products and Services}

There are a number of factors that should be considered in exporting products to Jamaica. This section provides a brief overview of many critical factors that must be considered.

\section{Establishing a Business}

Jamaica's Productions (JAMPRO) is the economic development agency with the objective of facilitating the establishment of businesses in both the productive and service sectors of the Jamaican economy. A potential investor should present a project proposal to JAMPRO for assessment and guidance. Information should include costs, financial projections, and production levels. Registration or incorporation of the business (e.g., sole proprietorship, partnership, or company limited by shares) should be made with the Registrar of Companies.

JAMPRO will assist with:

- obtaining applications to the income tax department (for an income tax number and for a business/trade number).

- obtaining import licenses from the trade board.

- identification of business location (factory space or land).

- applications for concessions under incentive legislation.

- applications to the revenue board for a Business Enterprise Number (BENO).

- work permits for nonresident personnel.

- registration under the consumption duty and/or excise duty acts.

To form a private, limited liability company, there must be at least two and a maximum of twenty shareholders. There are no restrictions on the nationality of subscribers. The two legal documents required to complete incorporation of a company in Jamaica include a memorandum of association and articles of association. 


\section{Distribution / Sales Channels}

Distribution and sales of imported merchandise in Jamaica are done principally through importers, distributors, and agent representatives. In addition, a large share of materials and supplies, including machinery and equipment, is imported directly by end-user firms. Close contact with end-users and provision of quality after-sales service at competitive prices are essential to maintaining position in the market. At the same time, because of relatively close proximity to the United States, many importers of goods into Jamaica maintain direct contact with exporters and manufacturers' representatives, particularly in Florida.

\section{Agents / Distributors: Finding a Partner}

Although the use of an agent or distributor is not required, it is frequently the best policy. A strong local representative can place product and generate sales that otherwise may not materialize.

Regardless of contract terms, every supplier and agent/distributor must abide by the Fair Competition Act (FCA). The FCA is designed to invalidate contract clauses that restrict competition. Under Jamaica's British common law system, once an agreement is reached and signed, it becomes a legally binding document. Breaches of contracts may be contested in a court of law.

The U.S. Department of Commerce's Foreign Commercial Service (USFCS) at the U.S. Embassy in Kingston, Jamaica can help U.S. exporters find agents and distributors through the International Partner Search (IPS), which provides a report on up to five qualified overseas agents, distributors, manufacturers' representatives, joint venture partners, licensees, franchisees, or strategic partners who have examined a U.S. company's materials and have expressed an interest in the company's products, services, or licenses, or have expressed an interest in otherwise partnering with the company. Requests for international partners can be made through any Export Assistance Center of the Department of Commerce, which will then involve the U.S. Embassy Foreign Commercial Service (FCS) in the search.
Other leads and sources for business partners include the local government investment agency, Jamaica Promotions Corporation (JAMPRO), the Private Sector Organization of Jamaica, the Jamaica Manufacturers Association, the Jamaica Chamber of Commerce, or the American Chamber of Commerce of Jamaica (which has offices in Kingston and Montego Bay).

\section{Direct Marketing}

While mail-order sales and catalogs have not been very popular, moves towards deregulation and liberalization in Jamaica have compelled persons in retailing to think of more creative ways of getting their message to customers and achieving sales growth. Some local firms have used direct mailings of promotional materials and telephone marketing. Local credit card companies sometimes target cardholders with direct mailings offering goods and services. Growth has been seen in network marketing for the promotion of products such as Avon and Amway.

\section{Franchising}

In recent years, there has been substantial activity in the area of franchising. Particularly notable is the growth in the number of fast-food operations. Current U.S. franchises include Kentucky Fried Chicken (KFC), Burger King, McDonald's, Pizza Hut, Subway, and Wendy's. Usually a locally registered company is responsible for managing the operation and ensuring conformity to the franchise requirements.

\section{Joint Ventures / Licensing}

Nonresident partners, unless exempted under one of the incentive programs, including corporate partners, are subject to Jamaican tax on their share of the partnership profits that accrue in or are derived from Jamaica. Nonresident foreign corporations pay tax on their share of profits at the same rates as resident corporations. Double taxation relief is available under the Convention for the Avoidance of Double Taxation, which entered into force in December of 1991. 


\section{Selling Factors / Techniques}

There are several large, established distribution companies in Jamaica that import and distribute a range of products. These companies typically own vehicles or have salesmen on contract with appropriate vehicles. Demand and, hence, markups for products vary. Because of proximity to and the strong influence of North America, strategies that prove successful in North America are generally successful in Jamaica as well.

\section{Advertising / Trade Promotion}

Advertising is primarily done through radio, television, the press, and billboards. There are several Internet service providers and two local TV networks. Radio is the most wide-reaching mass communication, with seven authorized stations. A number of advertising agencies have national coverage.

\section{Sales Service / Customer Support}

After-sales service has an important competitive advantage in the Jamaican market and is a requirement as an effective sales operator. If a U.S. firm has difficulty setting up its own distribution system, a local agent or distributor should be hired to maintain a trained service staff and to keep a reasonable stock of spare parts. As an alternative, the supplier could offer the customer rapid service from the United States.

\section{Product Pricing}

The market determines most prices in Jamaica. Notable exceptions are utility services (e.g., electricity, water, and bus fares). The Office of Utilities Regulation has been set up to monitor pricing and other activities for utility companies. Since 2001, competition in the telecommunications sector has helped to control some telecom prices. While there are no official or government policies on price regulation or control, the Fair Trading Commission (FTC) and the Consumer Affairs Commission (CAC) do monitor pricing of consumer items. The FTC generally responds to consumer complaints. The CAC plays a role in conducting research and informing the public of price variations.
The National Consumer League (a local NGO) plays a watchdog role.

\section{Selling to the Government}

Government procurement is generally done through open tenders, direct advertising, or by invitation to registered suppliers. American firms are eligible to bid. The range of manufactured goods produced locally is relatively small, so there are few instances of foreign goods competing with domestic manufactures. Companies interested in supplying office supplies to the government must register with the Financial Management Division of the Ministry of Finance (telephone 876-929-9330). Companies interested in supplying other kinds of equipment or materials should contact the National Water Commission (water supply and distribution equipment), the Jamaica Commodity Trading Company (for purchasing certain basic food items and fertilizer under concessionary loan programs), the Pharmaceutical Division of the Ministry of Health and Health Corporation Limited (medicines and medical supplies), and the Ministry of Housing (for housing and construction materials).

\section{IPR Infringement Protection}

The Jamaican Constitution recognizes property rights. There are laws designed to protect property and which specifically address protection of intellectual property. Bilaterally, there are also agreements covering intellectual property rights (IPR) protection. The United States and the government of Jamaica have signed an Intellectual Property Rights Agreement (1994) and have concluded a Bilateral Investment Treaty.

In June 1999, Jamaica's Senate passed three related pieces of legislation: the new Trade Marks Act, the Layout-Designs (Topographies) Act, and a bill to amend the Copyright Act to extend its coverage to include databases and the issue of trading in encrypted transmissions. All three have been enacted in fulfillment of Jamaica's obligations under the World Trade Organization (WTO) agreement on the trade-related aspects of intellectual property rights (TRIPS), the Paris Convention for the Protection of Industrial Property (to which Jamaica is seeking to become a signatory), and the bilateral agreement on 
intellectual property between Jamaica and the United States.

In general, Jamaica has reasonably good copyright and trademark protection regimes. However, Jamaica's patent regime is outdated and falls short of international standards. Jamaica was included on the Special 301 watch list as a result of lack of parliamentary action to bring patent, industrial design, and plant variety laws into conformity with international standards.

\section{Need for a Local Attorney}

It is advisable to retain professional advice at an early stage in a business venture to ensure smooth start-up and compliance with local laws. The Jamaica Bar Association has a membership of over 550 attorneys. The Association is located at 78-80 Harbour Street, Kingston (phone: [876] 922-2319). A list of members can be obtained from the Association. The Embassy can also provide a list of local attorneys.

\section{Agribusiness Industry Prospects}

The United States is Jamaica's number one trading partner, accounting for $48 \%$ of Jamaica's total importation of food, beverages, and tobacco. American exports of agricultural products to Jamaica made significant gains during 2001 and 2002, reversing the $7 \%$ contraction during 2000 , with $5.6 \%$ and $3 \%$ growth, respectively. The increase was mostly influenced by consumer-oriented products, which expanded to an all time high of US\$77 million, which was $13 \%$ higher than in 2000. Most individual consumer-oriented products increased to historic levels during 2002, such as snack foods, breakfast cereals, red meats, egg products, fruits, and vegetable juices. Wines and beers, processed fruits and vegetables, edible fish and seafood, and dairy products continue to show good prospects in the Jamaican market. Other suppliers include the United Kingdom, Canada, New Zealand, Guyana, and Trinidad and Tobago.

Over the last six years, Jamaica's total agricultural production, troubled with poor infrastructure development, adverse weather conditions, high interest rates, and low labor productivity, has shown a declining trend, resulting in declines of $16.6 \% 1.9 \%, 11.8 \%$, and $8.3 \%$ during 1997, 1998, 2000 and 2002, respectively. The declines were mostly observed in sugar, cocoa, and coconut. As the agricultural sector continues to perform sluggishly, Jamaica is expected to remain a net importer of agricultural, fish, and forestry products.

A significant market exists for U.S. agricultural products in the economically important and fast growing tourism sector. Approximately US $\$ 62$ million of Jamaica's total tourist expenditure goes towards the purchase of U.S. high-valued agricultural products. Hotels retain a strong demand for U.S. meats, cheeses, wines, fruits, temperate vegetables, seafood, salad dressings, and other specialty dairy products, despite the growth of "all-inclusive" properties.

The Jamaican consumer market, with a mean per capita consumption expenditure of US $\$ 1,714$, provides excellent opportunities for products such as potatoes, soft drinks and juices, frozen bakery products, fish, meat, poultry, cereals, general grocery products, and salad dressing. Food and beverages account for $48 \%$ of Jamaica's total consumption expenditure, of which meals-away-from-home represents the largest proportion (27\% in 2002). Meat, poultry, and fish account collectively for $22.5 \%$ of total food consumption, followed by $11.6 \%$ for cereals and cereal preparations, $8.8 \%$ for dairy products, and $5.4 \%$ for vegetable and fruit juices.

\section{Wines}

Long-term prospects for wines remain positive. Demand is driven primarily by the Hotel Restaurant sub-sector. The United States continues to compete with France and Chile for sparkling wines and with France, Canada, and Italy for other wines.

\section{Fruits / Vegetables}

Total imports of fruits and vegetables continue to grow as demand at both hotel restaurant institutions and retail remain strong. However, products, such as tomatoes, carrots, cabbages, melons, lettuce, and other fruits and vegetables, which compete directly with local products will become less price 
competitive under Jamaica's Safeguard Act. These products will still have reasonable demand during the characteristic cyclical periods of shortages. Garlic, onions, and other capsicums will remain competitive since local production is done on a limited scale and without the requisite market coordination.

\section{Pasta}

Imports of pasta and pasta sauces are expected to grow modestly as this item becomes more popular among consumers. American imports compete with imports from Guatemala and Costa Rica. Uncooked pasta has a CET of $30 \%$.

\section{Red Meats}

While beef and lamb consumption remains relatively low at the retail level, there is significant demand in the hotel/restaurant sector. Total market for imported beef, lamb, and goat meat is estimated at US\$15 million. The United States competes in specialty cuts of high-quality beef. Although goat meat has always been a principal component of the local cuisine, production has historically remained low, as Jamaica is yet to develop commercial techniques and genetics that suit the domestic situation.

\section{Cereals}

The Jamaican market for imported breakfast cereals is valued at US\$11.6 million. Cereals and cereal preparations account for approximately $8.8 \%$ of total food and beverage consumption expenditure in Jamaica. As the population becomes more health conscious, consumption of breakfast cereals and non-dairy milk substitute (e.g., soy milk) is expected to increase. While domestic productive capacity remains low, demand can be fulfilled with imports. Breakfast cereals from Trinidad and Tobago, the major supplier, are positioned in the lower income strata on the basis of price.priced U.S. cereals are prudently positioned in the less price sensitive market segments on the basis of quality.

\section{Snack Foods}

Under duty-free entry, Trinidad and Tobago and Barbados continue to dominate exports of snack foods to Jamaica. Snack products originating outside of the Caribbean Community (CARICOM) attract a $20 \%$ CET that renders them less price competitive when compared to products of CARICOM origin. Venezuela also maintains a strong presence in this market. The market is expected to show strong growth over the short to medium term.

\section{Trade Regulations and Standards}

\section{Trade Barriers}

As part of the continuing process of reforming the trade regime, the government initiated a tariff reform program, whereby duty rates were gradually reduced from as high as $200 \%$. Duties have been removed entirely from some categories. The Jamaica Bureau of Standards is becoming increasingly vigilant in monitoring the quality of imported items.

Under CARICOM's Common External Tariff (CET), Customs duties are prescribed on goods imported from countries outside the CARICOM region. Goods produced within the region under a Rules of Origin regime are not subject to import duties.

\section{Customs Valuation}

In 2001, Jamaica amended its Customs Act to allow a new system for valuing imports for custom duties under which WTO-prescribed Customs valuation methods were adopted. Also, as part of the modernization process, the structure and information system were modified to improve efficiency, accuracy, and transparency. Import duties are now levied on the transnational/invoice cost of products rather than on values arbitrarily assigned by Custom authorities. Due to deliberate under-invoicing to evade import taxes, the Customs Department still depends heavily on valuation based on "identical" and "similar" products. The amendment is part of an ongoing modernization of the revenue system, which will help Jamaica meet international trade obligations and bring the country in line with the Customs valuation regime of the WTO.

\section{Standards}

There are many mandatory standards to which products must conform before they can be exported to Jamaica. Copies of these can be purchased from 
the Jamaican Bureau of Standards. Jamaica generally follows U.S. standards in most cases. In recent years, the Bureau has become increasingly vigilant in terms of monitoring the quality of products sold on the local market.

\section{Labeling Requirements}

The Jamaica Bureau of Standards administers the Standards Act, Processed Food Act, and Weights and Measures Act. Products imported into Jamaica must meet the requirements of these Acts, and it is the responsibility of the importer and distributor to ensure that goods sold in Jamaica are properly labeled as required by the labeling standards. The Jamaica Bureau of Standards is very stringent in exercising its judicial authority to block the entry and sale of goods that are improperly labeled. A full description of labeling requirements is to be found in Labeling Standards JS1 Parts 1 to 29.

\section{Temporary Entry Provisions}

Importers may obtain authorization for temporary admission for a period of three or four months.

\section{Import Controls}

Although considerable headway has been made in the area of trade liberalization, there are still several items that require an import license. These items include milk powder, refined sugar, plants and parts of plants for perfume or pharmaceutical purposes, gum resins, vegetable saps, and extracts. The Trade Board, under the Ministry of Industry, Commerce, and Technology, is responsible for granting licenses.

If an item requires a license, it must be obtained from the Trade Board before the sale. The documents required for the importation of goods include a supplier invoice, certificate of origin, bill of lading, airway bill and other shipping documents, a declaration of value, and an import license, if necessary. (Certain products may also require phytosanitary certification.) When the goods arrive in Jamaica, the documents are submitted to the Customs authorities. Relevant duties must be paid before the goods may be cleared into the country. The importer may also be required to present a tax compliance certificate for the importer, a Business Enterprise Number (BENO), and a Taxpayer Registration Number (TRN).

Samples of commercial value brought into the country are dutiable at normal rates. However, the importer is entitled to reimbursement when taking the sample out of the country. This is effective on completion of a Revenue Deposit Receipt (RDR form) at Customs at the point of entry.

Jamaica prohibits the importation of the following agricultural items:

- all items banned under the Customs Act and the Plants Protection from Disease Act.

- all goods prohibited entry into the United Kingdom under the Anthrax Prevention Act 1919.

- animals and carcasses of animals prohibited under the Animals Diseases and Importation Act.

- brandy of a lower strength than 30 degrees per centum under proof, unless it is proved that it has been matured for a period not less than 10 years.

- essence of brandy or whisky or flavoring essences, except as approved by the Minister.

- oil of gin or cognac, except as approved by the Minister.

- rum coloring solutions.

- spirits and wine, unless specifically imported with casks or other vessels of at least nine gallons content or in glass or stone bottles with each case containing not less than one gallon.

- sugar, except under license.

\section{Export Controls}

Certain items are subject to export licensing, such as crocodiles, crocodile eggs, bird eggs, sugar, lignum vitae, and log wood, as well as live animals and shells subject to the Convention of International Trade in Endangered Species (CITES) administered 
by the National Resources Conservation Authority (NRCA) in Jamaica.

\section{Free Trade Zones / Warehouses}

Under the Jamaican Free Zones Act, investors are allowed to operate outside Jamaican Customs, solely with foreign exchange in certain activities such as warehousing and storing, manufacturing, redistribution, processing, refining, assembling,, packaging, and service operations (e.g., insurance, banking, and professional services). Incentives offered include a $100 \%$ tax holiday in perpetuity, no import licensing requirements, and exemption from Customs duties on capital goods, raw materials, construction materials, and office equipment. Free zone companies are allowed to sell $15 \%$ of their annual production in the local market with the approval from the Free Zone Administration.

Jamaica has three active industrial park/free trade zones: the Kingston Export Free Zone, the Montego Bay Export Free Zone, and Garmex. These free zones are government-owned and -managed.

\section{Membership in Free Trade Agreements}

Jamaica has enjoyed preferential tariff arrangements with the United States under the Caribbean Basin Economic Recovery Act (CBERA), or the Caribbean Basin Initiative (CBI), with the countries of the European Union under the Lome Convention, with Canada under CARIBCAN, and with other English-speaking Caribbean states under CARICOM.

In 2000, the U.S. Senate passed the Caribbean Basin Trade Partnership Act (CBTPA) to expand the benefits provided under the CBI to Caribbean firms that export to the United States. In effect, it will restore the margin of preferences CBI countries enjoyed prior to the implementation of NAFTA (North American Free Trade Agreement) as well as improve the range of economic opportunities available to the countries. Also, Jamaica has signed a Tax Information Exchange Agreement (TIEA) with the United States, which allows U.S. taxpayers to deduct legitimate business expenses incurred in attending business meetings and conventions in Jamaica.

\section{Investment Climate in Brief}

- The government of Jamaica welcomes and encourages foreign investment.

- There are no policies or regulations that reserve areas exclusively to Jamaicans.

- There are no barriers to foreign investment with regard to acquisitions and mergers.

- There are no restrictions on holding funds or hard currency or transferring funds associated with an investment.

- Buying or selling of foreign currency must be conducted through authorized foreign exchange dealers, cambios, and bureau de change.

- While foreign exchange is freely available, there is generally a waiting period of one to two weeks, depending on the amount, due to excess demand.

- There is no limit on the inflow or outflow of funds for any transaction, including remittances of profits, debt service, capital repatriation, capital gains, returns on intellectual property, or imported inputs.

- Property rights are protected under the Jamaican constitution. The purpose of any expropriation must be transparent and compensation for expropriated property must be adequate. The Embassy is not aware of any litigation between the Jamaican government and any private individual or company based on expropriation or on compensation for expropriation.

- There are no specific performance requirements imposed as a condition for investing in Jamaica. However, investments that attract hard currency and expand employment opportunities are favorably considered, some of those of specific interest to the agribusiness industry are:

- The Export Industry Encouragement Act.

- Approved farmer status under the Income Tax Act. 
- The Foreign Sales Corporation Act.

- The Industry Modernization Program.

- The Urban Renewal Act.

- Accelerated Depreciation/Special Capital Allowance.

- The government recently passed anti-dumping legislation and is considering safeguard legislation. A cumbersome bureaucracy has been identified as a major disincentive to investment in Jamaica. The approval process may involve 45 ministries and agencies and includes 30 approvals for most investment projects.

- Foreigners are allowed to borrow freely on the local market from a variety of credit instruments at market rates. The regulatory and accounting systems are consistent with international norms.

- There have been no recent incidents involving politically motivated damage to projects and/or installations. Crime poses a greater threat to damage foreign investments than do politically motivated activities.

- Violent crime, rooted in poverty, unemployment, and drug trafficking, is a serious problem in Jamaica, particularly in Kingston. Sporadic gang violence and shootings are concentrated in certain neighborhoods, but can occur in other areas.

- Jamaica has investment treaties with nine countries: the United States, Argentina, France, Italy, Germany, Netherlands, Switzerland, the United Kingdom, China, Cuba, Egypt, Indonesia, and Zimbabwe.

- Jamaica has a bilateral investment agreements and a double taxation agreement (DTA) with the United States, as well as with many other countries.

- Labor is generally available at a relatively low cost. However, there is a shortage of technically skilled labor.

\section{Business Customs}

\section{Travel Advisory and Visas}

American citizens can enter the country with either a passport or proof of citizenship (a certified true copy or original birth certificate) and a photo I.D. (e.g., valid driver's license). No visa is required. However, U.S. citizens visiting for business will require a business visa, which can be obtained from a Jamaican Consulate in or near their home state.

American business travelers are encouraged to obtain a copy of the "Key Officers of Foreign Service Posts: Guide for Business Representatives" available for sale from the Superintendent of Documents, U.S. Government Printing Office, Washington, D.C. 20402 (telephone 202-512-1800; fax 202-512-2250).

\section{Business Infrastructure}

The normal working day for government offices and factories is 8:30 a.m. to 5:00 p.m. Monday through Thursday, and 8:30 a.m. to 4 p.m. on Fridays. Government offices are closed Saturday and Sunday.

Almost all commercial businesses are open on Saturday, but few open on Sunday. Jamaica is on Eastern Standard Time (EST) year-round and does not observe daylight savings time.

Jamaicans are a little more formal than North Americans. Generally, Jamaican business acquaintances, after a courteous and friendly first greeting, will respond quickly to informality.

The Jamaican dollar is the unit of currency and is composed of 100 cents.In July of 2003 the Jamaican dollar was valued at a weighted average of about one USD = JD 58.96 (average bank selling rate).

\section{Useful Web Sites}

\section{JAMAICA:}

- Statitical Institute of Jamaica http://www.statinja.com

- Seaports of Jamaica http://www.seaportsofjamaica.com 
- Jamaica Trade Point

http://www.jamaicatradepoint.com

\section{UNITED STATES:}

- USDA Foreign Agricultural Service http://www.fas.usda.gov

- US Export Programs Guide http://infoserv2.ita.doc.gov/ticwebsite/tic.nsf/ AF34FA880278BDD5825690D00656C6F/ F69FDCF72B7713B58525691900746F18?Open Document

- Internet Guide to Trade Leads http://infoserv2.ita.doc/gov/ticwebsite/tic.nsf/ 504ca249c786e20f85256284006da7ab/ ef7db94aef24919885266470049c1cd?OpenDocu ment

- US Trade Finance Resources http://infoserv2.ita.doc.gov/ticwebsite/tic.nsf/ AF34FA880278BDD5825690D00656C6F/ F69FDCF72B7713B58525691900746F18?Open Document

- Basic Guide to Exporting http://www.unzco.com/basicguide/index.html

\section{HEMISPHERIC:}

- Hemispheric Guide on Customs Procedures http://alca-ftaa.iadb.org/hgcp_eng.htm

- Hemispheric Trade and Tariff Database http://alca-ftaa.iadb.org/eng/ngmadb_e.htm 